ISSN 2073-4441

www.mdpi.com/journal/water

Review

\title{
Hydrogeological Characteristics of Hellenic Aqueducts-Like Qanats
}

\section{Konstantinos S. Voudouris ${ }^{1, *}$, Yiannis Christodoulakos ${ }^{2}$, Emmanouil Steiakakis ${ }^{3}$ and Andreas N. Angelakis 4,5}

1 Laboratory of Engineering Geology \& Hydrogeology, School of Geology, Aristotle University, Thessaloniki 54124, Greece

2 25th Department of Antiquities, Ministry of Culture, Chania 73134, Greece;

E-Mail: gchkeepka@yahoo.gr

3 Mineral Resources Engineering Department, Technical University of Crete, Chania 73134, Greece;

E-Mail: stiakaki@mred.tuc.gr

4 National Agricultural Research Foundation (N.AG.RE.F.), Institute of Iraklion, Iraklion 71307, Greece

5 Hellenic Water Supply and Sewerage Systems Association, 41222 Larissa, Greece; E-Mail: info@a-angelakis.gr

* Author to whom correspondence should be addressed; E-Mail: kvoudour@geo.auth.gr; Tel.: +302310998519 .

Received: 19 July 2013; in revised form: 23 August 2013 / Accepted: 28 August 2013 / Published: 11 September 2013

\begin{abstract}
In ancient Hellas, water management began in the early Minoan Era (ca. 3200-1100 BC) and was related to the geomorphology, the geology, the topography, and the local climatic, hydrological, and socio-political conditions. Historical and archaeological evidences show that ancient Greeks had developed even qanat-related technologies since the Classical times. During democratic periods, the focus of water management was on sustainable small scale, safe, and cost effective management practices, and institutional arrangements, whereas in oligarchic periods, emphasis was on the construction of large-scale hydraulic projects, including aqueducts and/or qanats, mostly related to the public sectors. Aqueducts-like qanats are gently sloping, artificially constructed underground galleries, which bring groundwater from the mountainous area to the lowlands, where water is used, sometimes several kilometers away. It is worth noticing
\end{abstract}


that no large-scale lifting techniques were available, and water was transferred from the source (usually a spring) by aqueducts (qanats) from a higher elevation to a lower level by gravity. Historically, the aqueduct-like qanat technology was developed by Persians in the middle of 1st Millennium BC, and spread towards the Arabian Peninsula and Egypt. The expansion of Islam led to diffusion of qanats in Mediterranean countries (e.g., Spain, Italy, and Cyprus). Much of the population of Iran and other arid countries in North Africa and in Asia depend on water supply by aqueducts-like qanats, even today. This technology is characterized by its durability and sustainability, although an aqueduct-like qanat is expensive, both in construction and maintenance. It is pointed out that, the technique of tunneling was used during the Classical period in ancient Hellas. Since the well known tunnel at the island of Samos, Hellas, was designed and constructed by Eupalinos (ca. $530 \mathrm{BC}$ ), several underground tunnels (with and without well-like vertical shafts) in order to convey water from one location to another one located in a lower level were implemented in this country. Several aqueducts (qanat) paradigms (e.g., in Athens, on islands of Crete and Rhodes, and in the area of Serres in north country), which are in use even today, are presented and discussed. Overall, it seems that water-related problems of modern societies are not very different from those during antiquity.

Keywords: aqueducts; Crete; foggara; Hellas; Polyrrhenia; qanat; Rhodes; Serres

\section{Prolegomena}

Urban hydraulic works, and especially aqueducts, are known to exist since the Bronze Age (ca. 3200-1100 BC). Several aqueducts are described in Minoan Crete, Hellas, by Angelakis et al. [1]. In addition, an unknown civilization (ca. 2600-1900 BC) in Indus valley at Mohenjo-Daro, Harappa, and Lothal developed a sophisticated system for water supply and sewage [2]. Water came from more than 700 wells and supplied not only domestic demands but also a system of private baths and a Great Bath for public use [3].

In addition, the Mesopotamians were not far behind [4]. In the Sumerian city of Nippur, the excavations exposed clay pipes as well as tee- and angle-joints [2]. Rainwater harvesting and collection in cisterns for urban water supply was practiced at about the same period in Jawa in Northeastern Jordan [5]. Another collection system, this time for groundwater, was probably developed in Persia, again in the same period [6]. This is the well-known as "qanat" technology.

Qanat is a system of water supply consisting of an underground tunnel connected to the surface by a series of shafts which uses gravity to bring water from the water table of the higher elevetion lands to the surface of the lower elevetion lands. The word qanat comes from a Semitic word meaning "to dig" and, over the centuries, the technology was transferred to other civilizations and become known with different names such as: hydragogeion, e.g., aqueduct (from the words hydro = water and agogos = conduit, Hellas), "karez" (Afghanistan and Pakistan), "kanerjing” (China), "falaj" (United Arab Emirates), and "foggara/fughara" (North Africa). According to UNESCO recommendations, some of those projects are protected as monuments of world heritage [2]. The pure qanat probably 
developed as a by-product of mining where, when groundwater was struck, this water was removed from the mining site by digging a channel or tunnel to drain it away [7]. A typical cross-section of a qanat is shown in Figure 1.

Figure 1. A typical cross-section of a qanat [8].

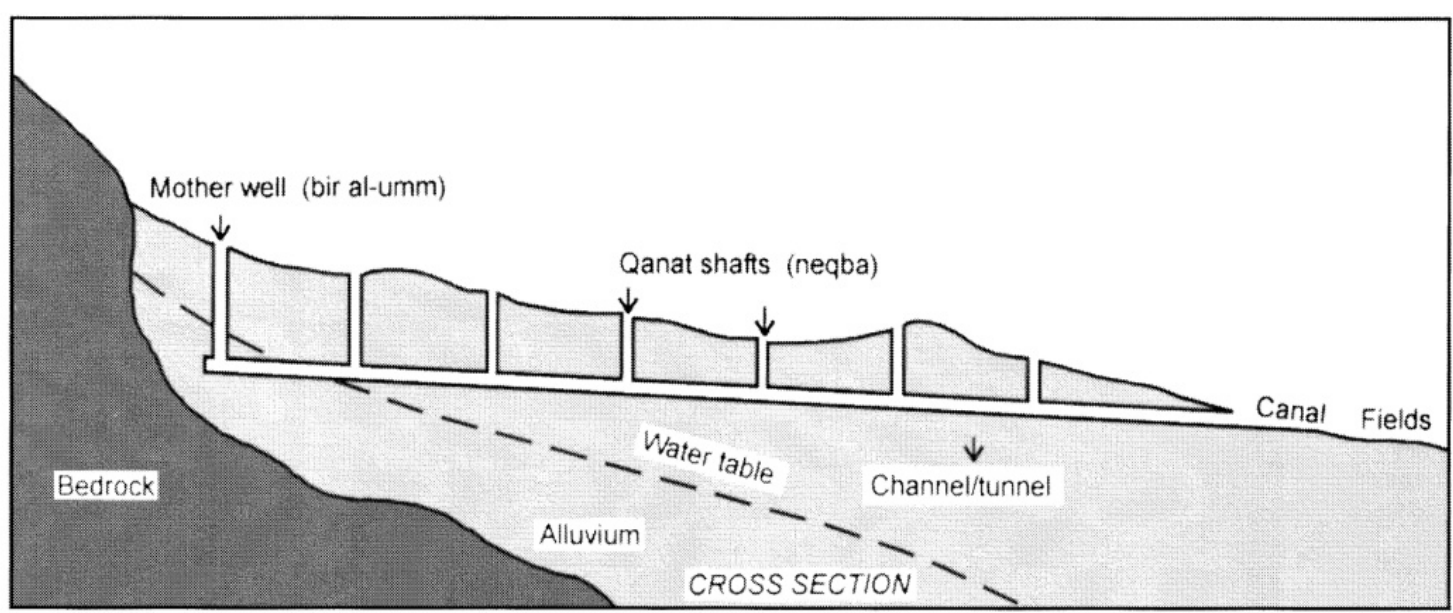

In several areas of the Arabian Peninsula, beginning in the middle of the 1st Millennium, and for several centuries after, hydraulic works were mounted to convey water from mountain aquifers, via subsurface aqueducts, onto drier valleys and plains [8]. Such subterranean, gravity-driven galleries, were developed first by Persians, and later by others (e.g., Algerians, Omanis, Libyans, Moroccans, Tunisians, and Egyptians) who borrowed their technology. This technology and its application has been in use a very long period of time, e.g., Iran and Algeria, where a significant percentage of water used in these countries for irrigation and domestic consumption was provided by such systems [9]. However, aqueduct-like qanat technologies were known in Central Europe since the Classical period [10,11]. In addition, Romans developed similar technologies in Luxembourg, Croatia, Spain, Germany (Trier), Italy (South), and Hellas [12,13] (Figure 2).

Figure 2. Areas and places of aqueduct-like qanats evidence in European countries [13].

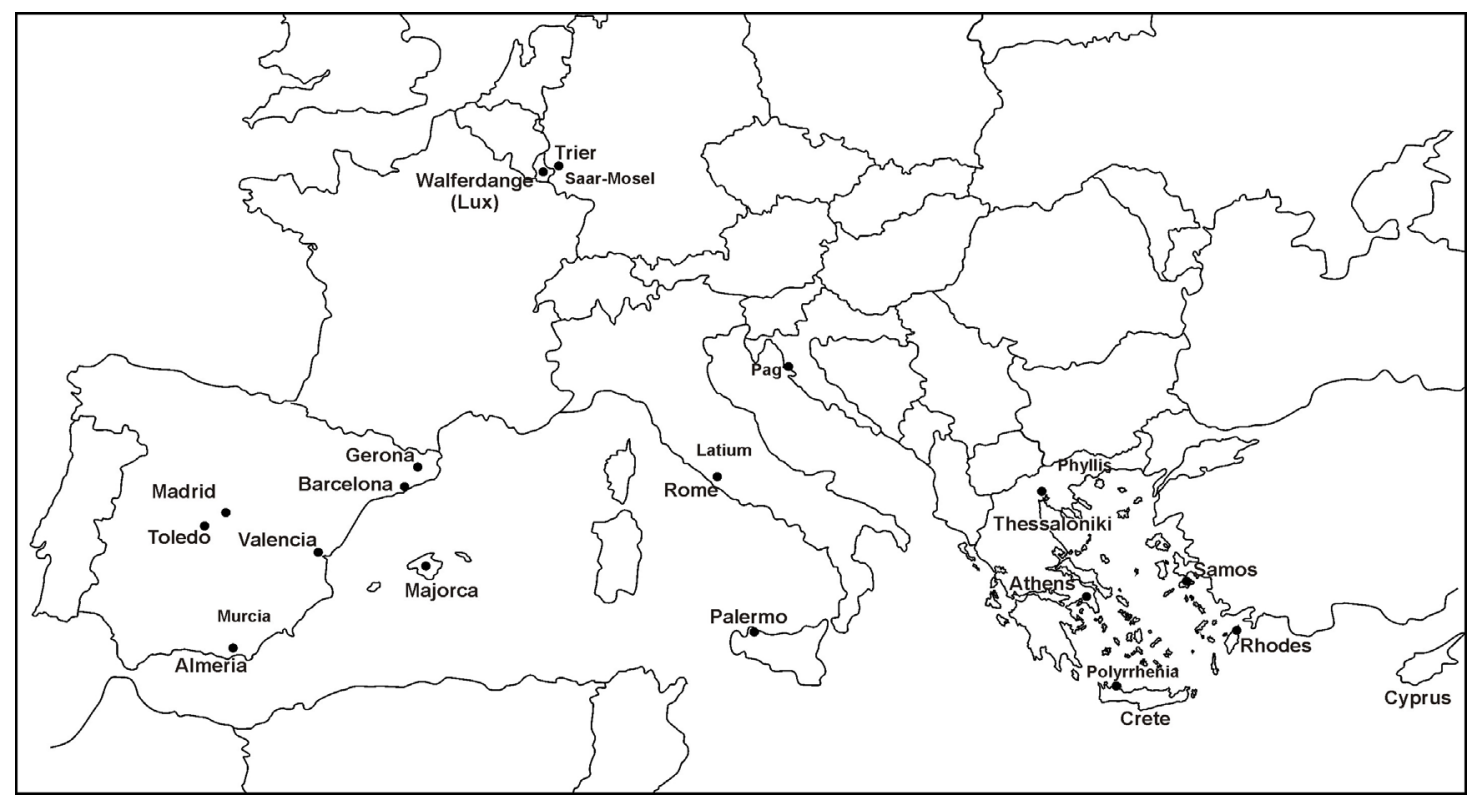


In addition, similar water supply technologies reappear after the Romans, together with monasteries. During the Middle Ages, the Fulbert-gallery (Maria Laach, Germany) and the Mönchsberg tunnel (Salzburg, Austria) are referred as the most important tunnels built with qanat technique [10]. In Spain numerous qanats (viajes de agua, in Spanish) were in use since the beginning of the 17th century and were the golden era of Madrid's qanats (such as Fuente Castellana, Amaniel qanat, and Alto and Bajo Retiro). This became apparent in Madrid after it became the capital of Spain in 1561. It was reported that, the capital Madrid was supplied by water until 1859 by a network of qanats with a total length of $120 \mathrm{~km}$ [12]. However, the Alcubilla qanat, already operational in the year 1400 , has a total length of $12 \mathrm{~km}$ (including its tributary branches) [12].

In Hellas, aqueducts-like qanats, engineered under surface canals to collect ground water, not necessarily reaching the groundwater table, were known in several places of the country in Classical times. One of the oldest, most well-known aqueducts, based on tunneling in Hellas, is that of Eupalinos, in Samos, from the 6th century BC and was already described by Herodotus [14,15]. The technology is thought to be adopted from the Persians [13]. However, the water supply of antique cities, like Naxos and Korinthos during the Classical period, had also been secured by galleries, constructed with qanat-like techniques $[14,16]$. Within the 6th century BC, the combination of subsurface water conduits and vertical aeration shafts was typical for many Greek water supply systems $[13,16]$. Such technologies were implemented furthermore during the Roman and Ottoman periods.

This study is focused on the technological developments and management practices related to aqueduct-like qanat technologies in Hellas. In the following sections, such technologies, which were practiced since the Classical period, are considered. Remarkable hydraulic works of aqueduct-like qanat technologies were also implemented in Hellenistic Athens and Polyrrhenia in Western Crete. In addition, significant achievements made in terms of such sustainable and cost efficient water management practices in the island of Rhodes during the Roman period and in the area of Phyllida (Serres) in Northern Hellas, and much later during the Ottoman period. Paradigms of these technologies and management practices presented in this article (not widely known among engineers) may have some importance for water engineering, even in modern times. The hydraulic features of aqueduct-like qanat systems in Hellas, through the centuries, are described and discussed. Finally, an attempt to clarify the qanats as a category of the aqueducts instead of an independent technology is undertaken.

\section{Athens Aqueducts}

The water supply had always been a difficult task in Athens due to the low water availability of the region. Water was transferred from the source (usually underground) from a higher elevation to a lower level by gravity. Thus, traditionally, the water supply of the city was depended on the transport of water through aqueducts-like qanats, based on tunneling and vertical wells (shafts) at intermediate horizontal distances ranging from $50 \mathrm{~m}$ to $70 \mathrm{~m}$. Several aqueducts are known in the region since Classical Hellas. Some ancient aqueducts derived water exclusively from springs, whereas others combined water from springs and underground capture as well. Although spring water was preferred, it was not sufficient; the ancient aqueducts in Athens were intentionally designed to capture additional underground water, in order to increase the flow rate and reduce the effect of periodic fluctuations of 
the springs in summer [16]. The most significant ancient aqueducts of Athens are shown in Figure 3. A continuous improvement of the engineering solutions applied in the ancient aqueducts is revealed; younger aqueducts advance older techniques and carry water from more distant sources. A sequence of aqueducts, which capture underground water, was finally followed by the surface transport of water from springs, in the 5th century $\mathrm{AD}$, when Athens declined in population [16].

Figure 3. The most significant ancient aqueducts of Athens [16]. (1) Hymettos; (2) Long Walls; (3) Acharnian branch: 3.1 and 3.2 hypothetical end sections; (4) Hadrianic; and (5) Late Roman: 5.1 Kifissia branch, 5.2 Herakleion branch, 5.3 and 5.4 hypothetical end sections.

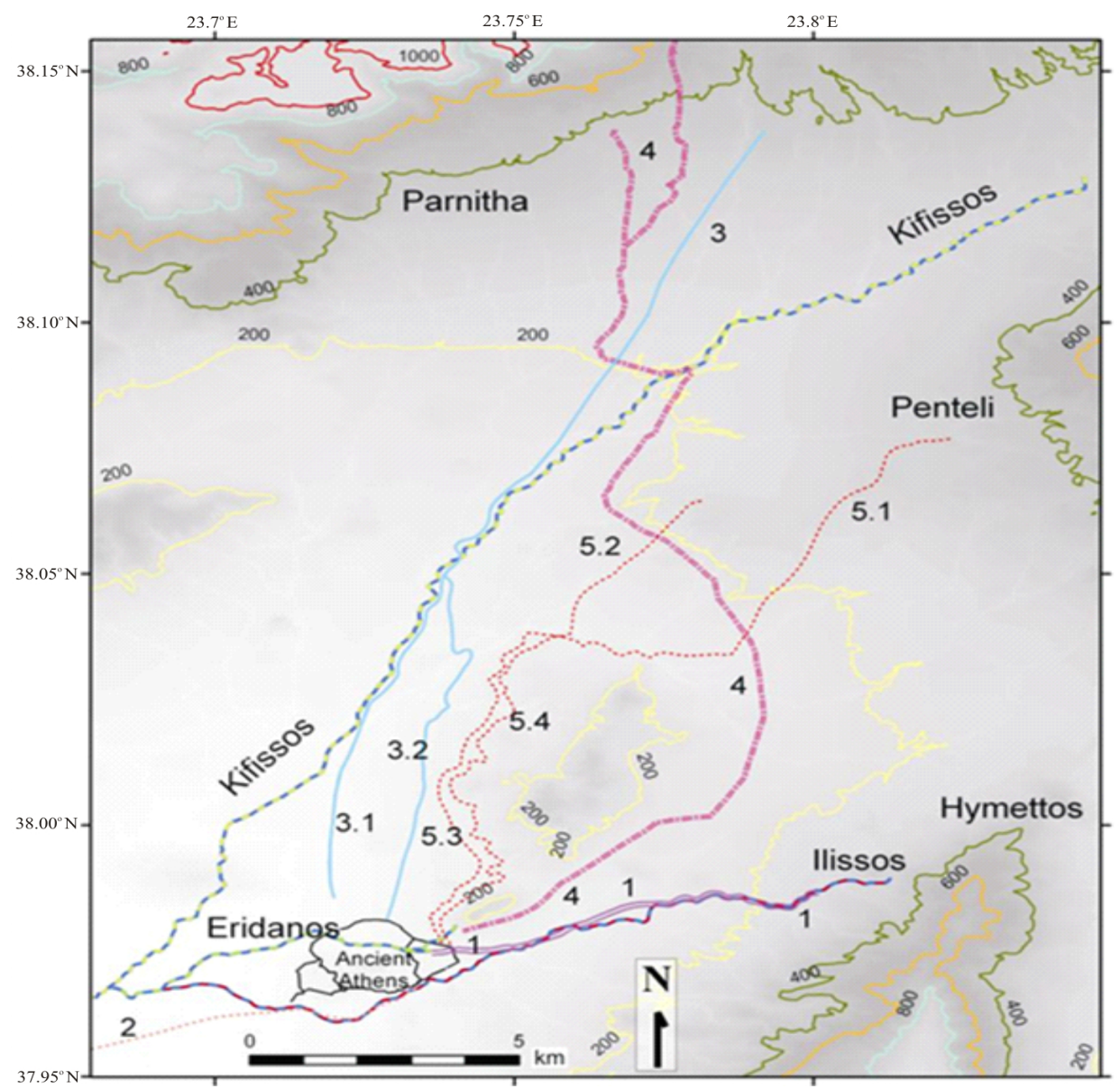

The geological setting of the ancient aqueducts of Athens is examined with particular emphasis on the hydrogeological and geotechnical aspects and a detailed description of the aqueducts, their approximate routes and the respective distribution nets were recently published with an extensive citation of references [17-19]. One of the salient characteristics of the water supply system of Athens in the Classical and Hellenistic periods was the sustainability and durability of the system. The stability of the ancient tunnels is correlated with the surrounding geological formations; it turns out that the stability problems of the ancient tunnels are comparable to those met in the tunneling works of Metro lines, particularly in the Athenian schists [16]. 


\section{Polyrrhenia Aqueducts}

Ancient Polyrrhenia lies in the mountainous hinterland of the Kissamos district in the prefecture of Chania. It has been one of the most important cities in Crete, in a naturally protected site. According to Strabo it was founded by Achaeans and Lacedemonians. Interspersed settlements were integrated to a fortified town. During Hellenistic times it grew strong and stood against neighboring Phalassarna. Its coins date from $c a$. 4th century BC to the Roman times. Following this, it flourished as it was spared sacking for not having fought against Romans as other Cretan cities did. The ancient town was surrounded by walls, of which a great part is preserved. In addition, there is a byzantine fortress on the acropolis. Walls are reinforced by means of towers.

The terrain of Hellenistic Polyrrhenia in Western Crete is hilly, with soil terraces and shady glens deprived of spring water that could meet the needs of a town or even the modern village (Figure 4). How was the water supply ensured to the ancient town? Surviving data provide the necessary information but the lack of systematic excavations greatly limit concluding remarks. During the Hellenistic period, the walled area of the town was 17.55 ha, with walls of a total length of $2652 \mathrm{~m}$. At that time, the houses turned mostly on the leeward points (the whole town facing south), and rock was excavated not only for structural purposes but also for collecting rainwater in cisterns (Figure 5). The cisterns have a narrow mouth at ground level, looking like wells, and they extend downwards in the shape of a bottle. Water from these cisterns was drawn up using pots and ropes. There is no evidence of water transportation by pipes and/or conduits. These cisterns were used for water supply of individual homes and perhaps small neighborhoods.

Figure 4. General view of ancient Polyrrhenia (with permission of D. Tzortzakis, archive of the 25th Ephorate of Antiquities, Chania, Hellas).

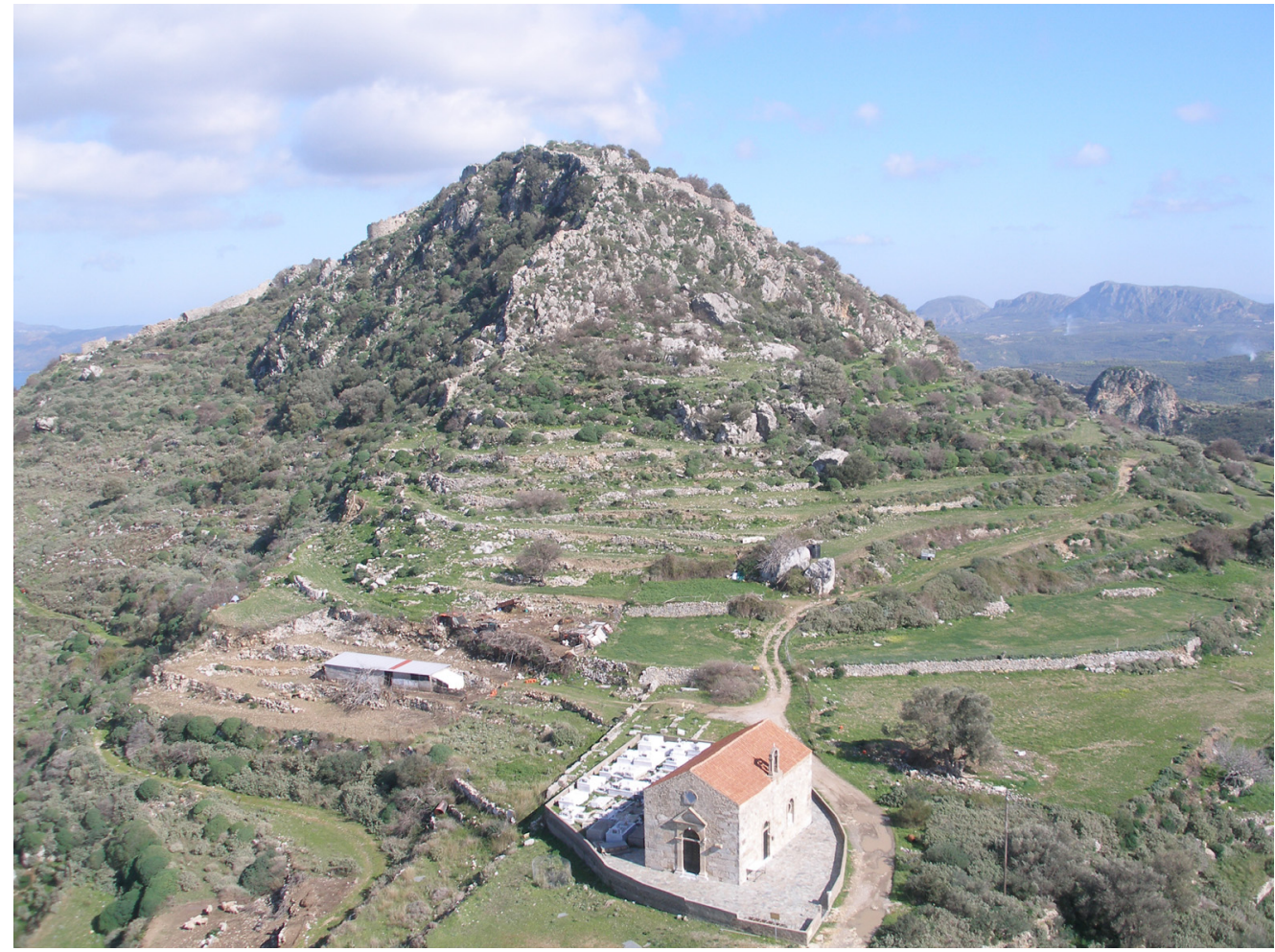


Recently Christodoulakos and Markoulaki [20] reported that two aqueducts of the Hellenistic period (from the end of 4th to the end of 1 st century BC) have been restored and reused during the Roman times, being still in use today. They are carved by tunneling through natural marly limestones on the southern low slopes of the city. Here is a brief description of these aqueducts.

Figure 5. Mouth of subterranean cistern in a Hellenistic house in the ancient town of Polyrrhenia.

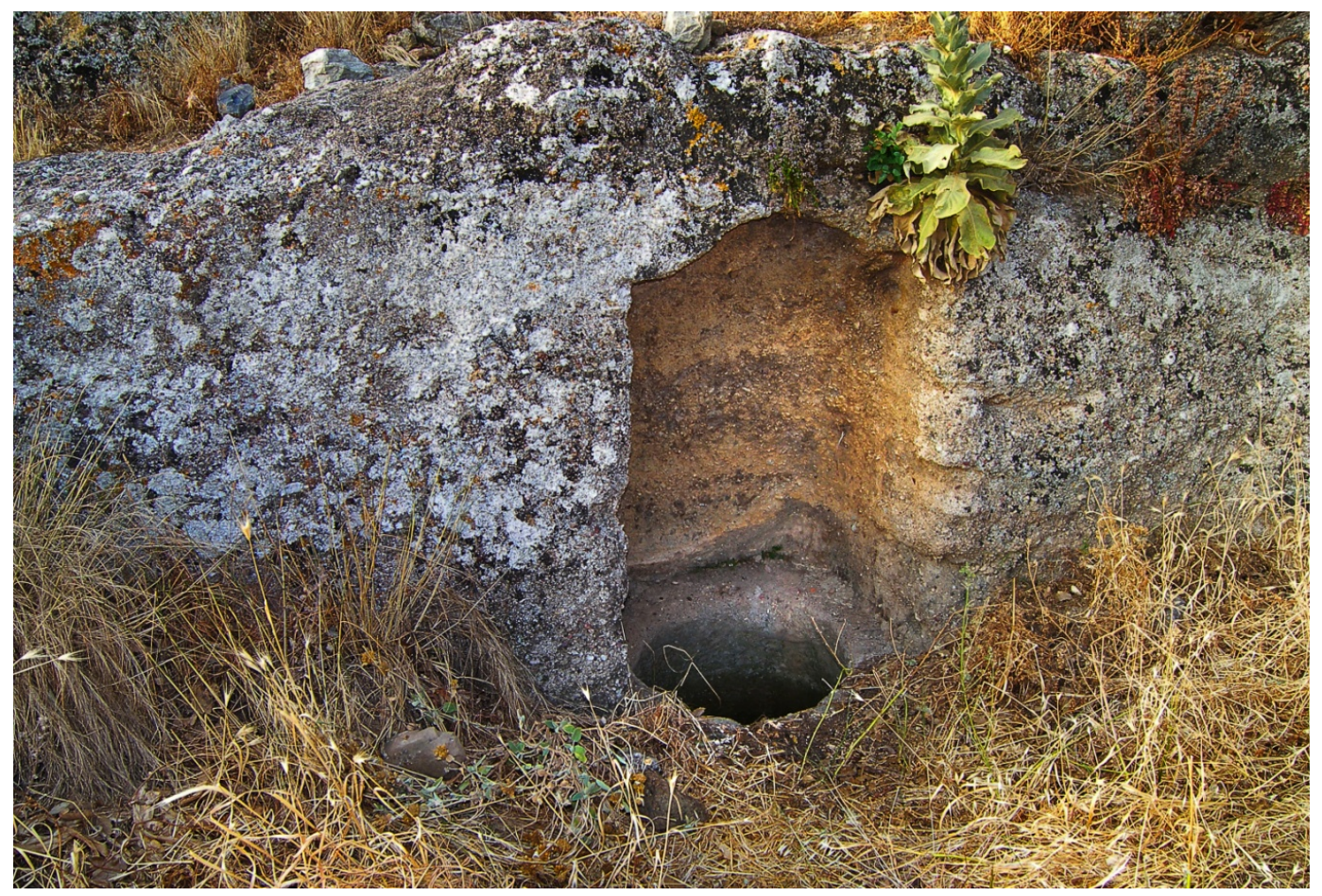

Aqueduct No 1. Aqueduct (tunnel) no 1 ends in the modern village central square. Christodoulakos and Markoulaki [20] have visited the tunnel in its length of about $65 \mathrm{~m}$ (Figure 6). Its continuation is obstructed by stalactite-like rock. The height of the tunnel is at least $2.00 \mathrm{~m}$ and its width of about $0.80 \mathrm{~m}$. There is no distinct conduit or channel in the bottom of the tunnel, and the water flows to the slight slope. It is covered by a thick layer of salts, which do not allow full investigation. Calcium carbonate deposited by water dripping, from the ceiling, gradually forms stalactites.

At the exit of the tunnel, along its western wall, a secondary, shallow rock-cut channel runs at a level of +1.00 over the "floor" of the tunnel.

Moreover, at tunnel's outlet there is a cistern with dimensions of $18.20 \mathrm{~m} \times 6.70 \mathrm{~m} \times 3.50 \mathrm{~m}$ (Figure 7). It was used as cistern, where the water flows by gravity; perhaps a mobile barrier in the tunnel was used to lead the water into the cistern (Figure 8).

In addition, in front of the tunnel's outlet, a fountain seems to have existed. Two large stone basins, used to this date, as well as a shallow channel printing the water flow on the rocky terrain, may be supporting evidence.

Higher than the supposed fountain, cuttings on the rock may have been connected to a nymphaeum. It is worth noting that this same aqueduct ensures a continuous flow of water throughout the year up to this day [20]. 
Figure 6. Exit of the tunnel; and channel of aqueduct 1 [20].

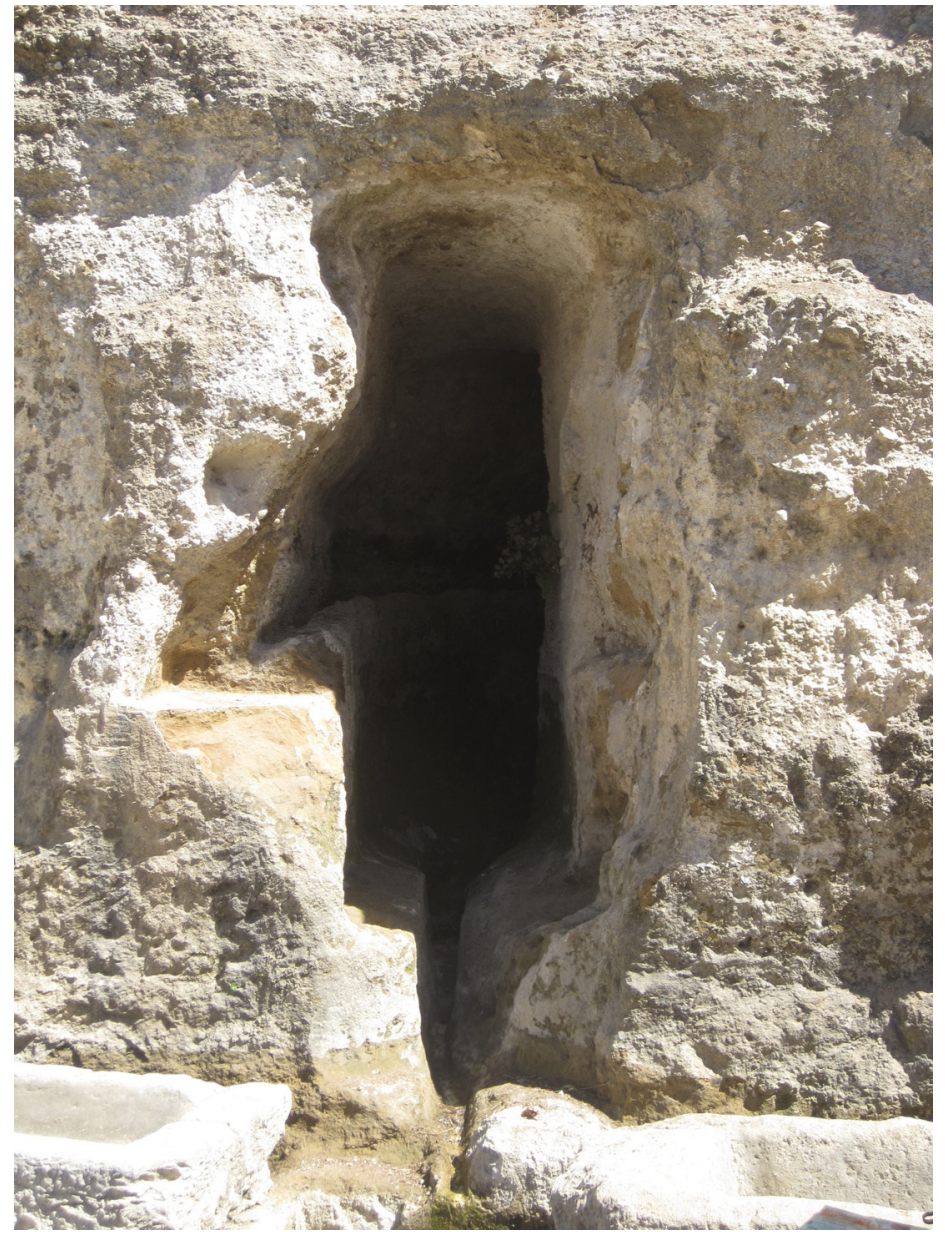

Figure 7. Rock-cut cistern at the end of aqueduct 1 [20].

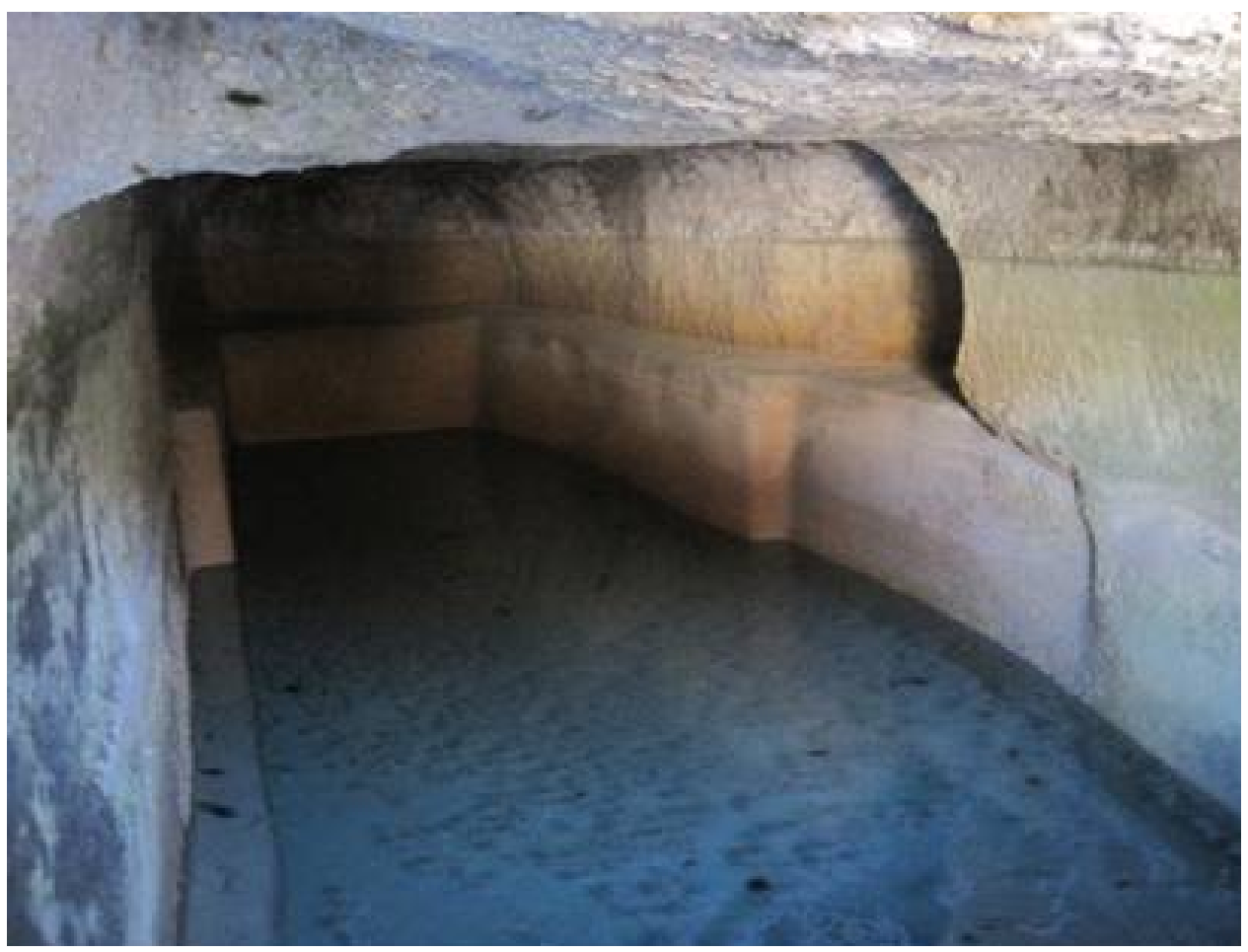


Figure 8. Part of the tunnel of aqueduct 1 [20].

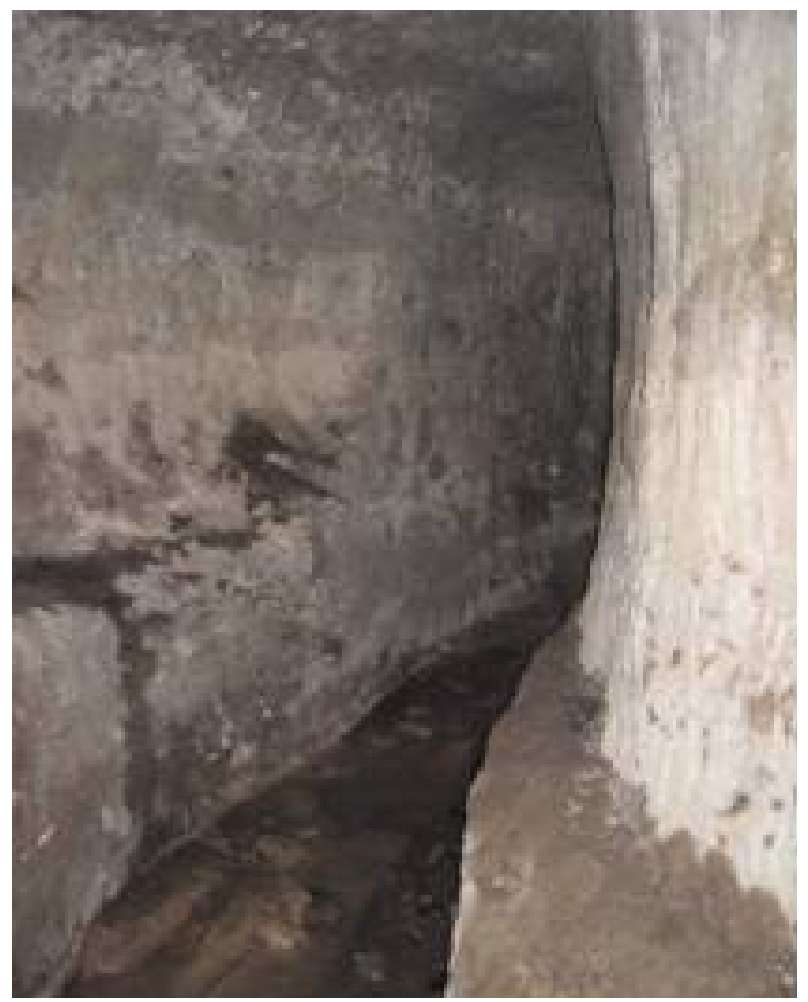

Aqueduct no 2. In the southeastern edge of the modern village, one can see the end of another similar tunnel (Figure 9). This tunnel, constructed roughly in the same way as the previous one, supplies the village with a continuous flow of water all year long [20]. There is a channel on the floor of the tunnel, partly constructed with stones, partly carved into the rock, which ends up at a fountain (Figure 10).

It is worth noting that aqueducts ended in cisterns to ensure water storage for emergency cases such as prolonged drought. At a horizontal distance of $98.5 \mathrm{~m}$, on a roadway, there is a rock-cut staircase going down the tunnel. According to the inhabitants, the staircase was connected to the tunnel. Near the tunnel exit there is a rectangular hole measuring $2.00 \mathrm{~m} \times 1.50 \mathrm{~m}$ that also led to the tunnel. It has been filled in with earth, which makes it difficult to observe [20].

Thus, two aqueducts have been identified in ancient Polyrrhenia: one in the surroundings of the semicircular tower and the other one at the southeastern end of the village. Two independent strands of partly explored tunnels were collecting water to supply the ancient town. This is clear if we determine the elevation of the bottoms; the first tunnel lies at a level of $+265 \mathrm{~m}$, while the second one at elevation of $+246 \mathrm{~m}$. It is known that the flow channel should be almost horizontal with a slight slope ranging

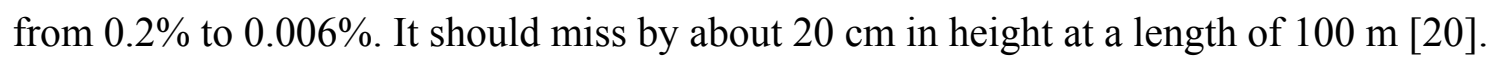

In the south of Polyrhenia village, flysch formations are overlain by Neogene formations (Figure 11). The latter consist of thick-bedded to unbedded limestone, white to white-yellow, evolving upwards to grey-yellow, and clayey-marly formations with silt and sand intercalations. Wide spread joint systems and localized fissures, induced by compressive forces and probable faults, have a pronounced effect on the movement of water in the flysch beds. The result is that groundwater flows mainly through the limestone beneath the flysch and the permeable layers of flysch formation as well. Following this, it 
seeps out along the aqueduct-tunnels (Figure 10). Based on the above, the water supply system in ancient Polyrrhenia, cannot be considered only as a simple water supply system, but as a dynamic drainage ditch that drains water from the geological formation(s) to a permanent installation.

Figure 9. Tunnel with channel along the semicircular tower of the Hellenistic wall [20].

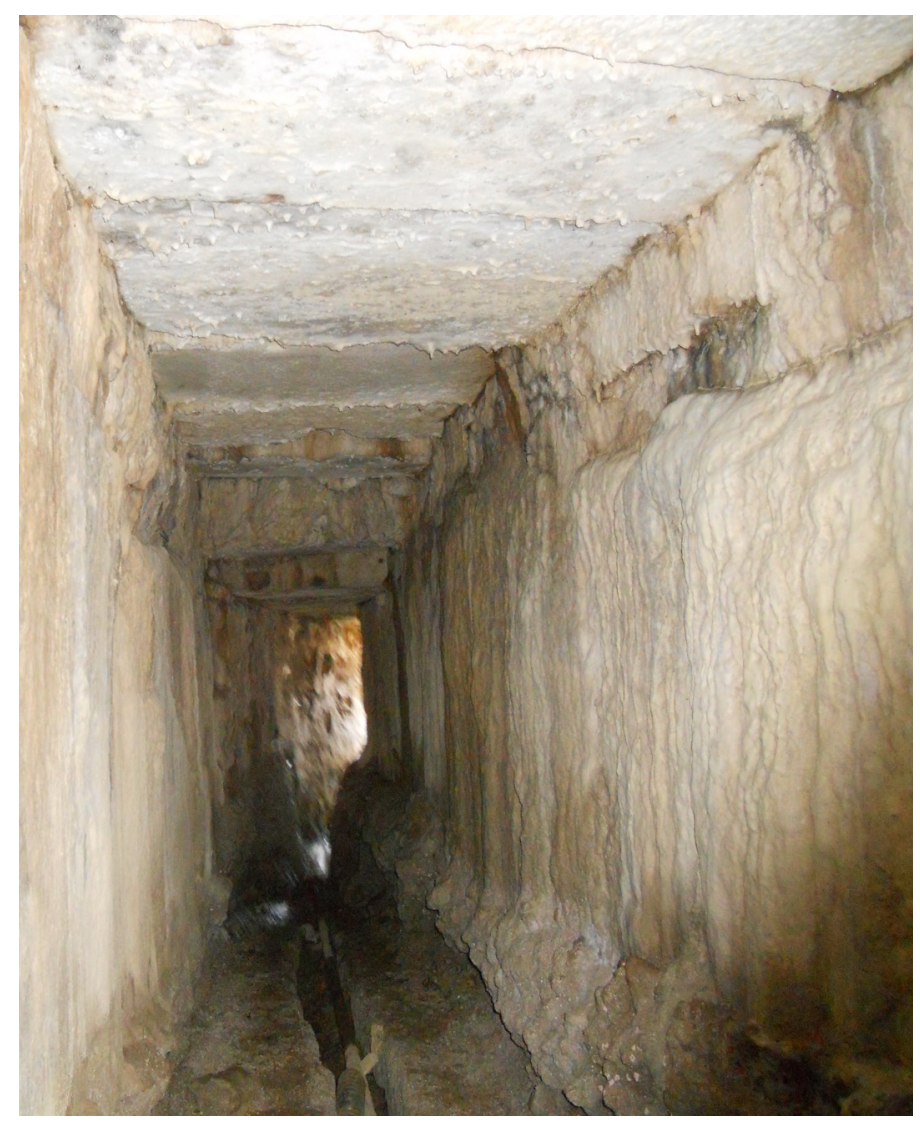

Figure 10. Fountain of the early 1960s in which the water from aqueduct 2 ends up to [20].

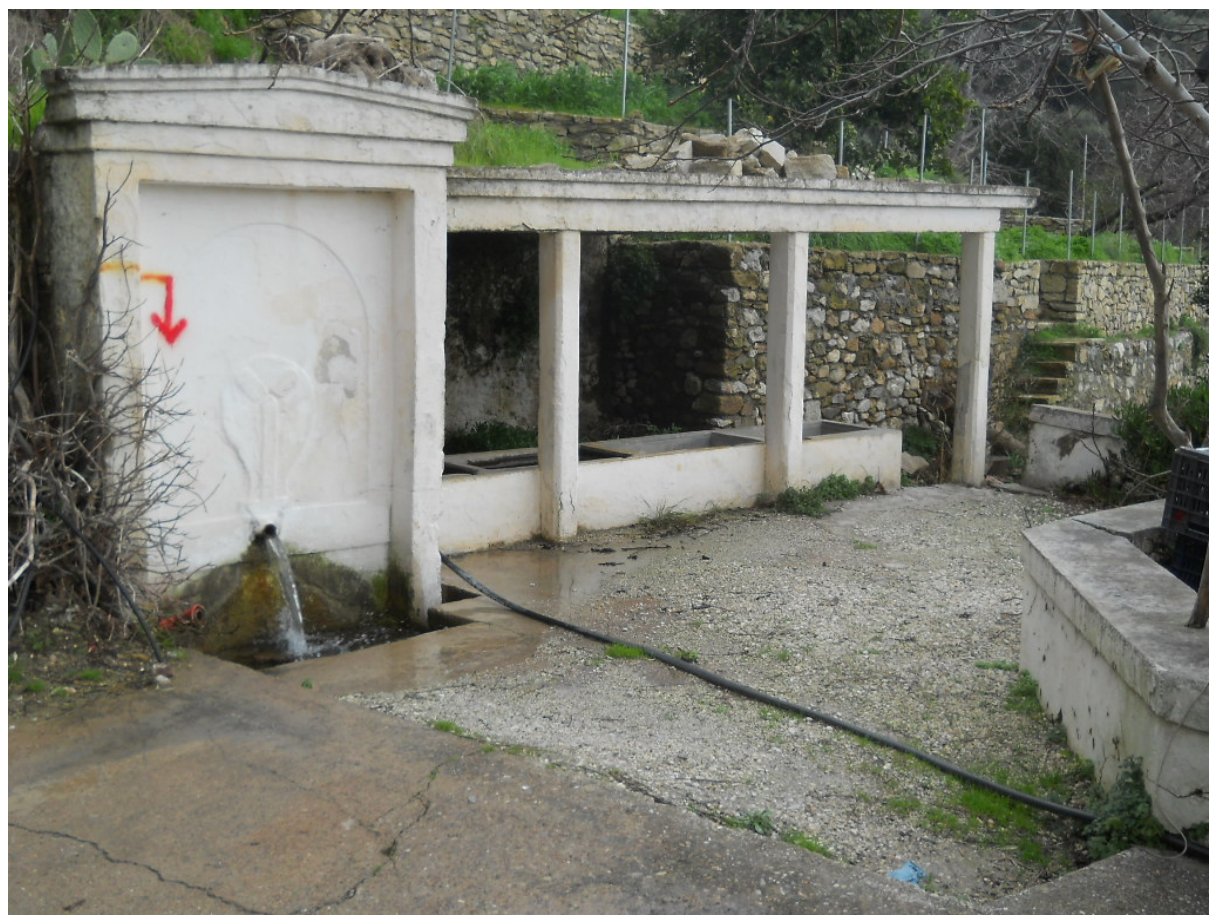


Figure 11. Simplified cross section illustrating different geological formations and the aqueduct tunnels in Polyrrhenia.

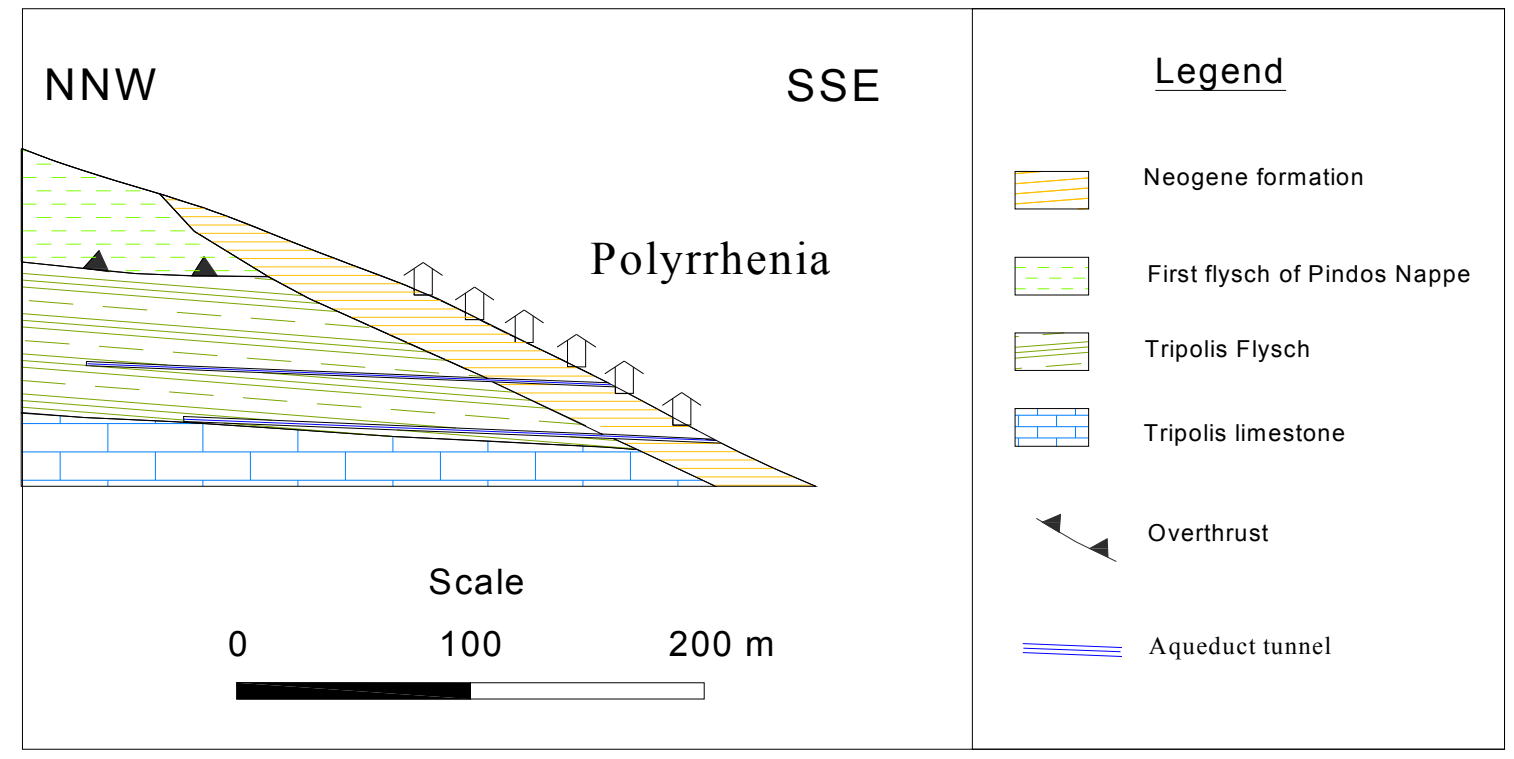

According to these data, but mainly because tunnels collected water from an underground water basin or well, rather than from a surface spring, these aqueducts should be classified as qanat systems [21]. Such systems are still used in Middle and Far Eastern countries and are considered as being invented mainly by the Persians [22].

Contrary to other aqueducts in Western Crete e.g., at Elyros, Syia, Marathi, Phalassarna, and Gavdos, where a channel carried water from a surface spring, no such spring has been detected at Polyrrhenia. We should assume that constructors of the aqueducts identified one or more underground water basins and could bring water to the surface by means of tunnels. For this reason, the tunnel should be opened almost horizontally with reference to the water table, and water should be brought to the surface in need of water by means of the tunnel.

The difficulty of such a project is evident. The underground water basin should initially be identified by means of a well reaching a depth of $40 \mathrm{~m}$ below ground surface. The topographical accuracy was very important for digging, as it involved no rectilinear tracing. In the case of Polyrrhenia, the system of collecting and transporting water through a qanat-type tunnel may be considered more as a dynamic system of reliable water channeling (drainage ditch), from a hydrogeological basin to a permanent settlement, rather than as a simple aqueduct.

\section{Aqueduct of Rhodes}

The town of Rhodes is situated in the northeast tip of the island (southeast of the Aegean Sea) and forms a triangle from north to south. The urban plan of ancient Rhodes reflects directly the urban and philosophical ideas of the famous ancient Greek planner, Hippodamus. The street plan of the ancient city is known due to decades of archaeological excavations. The ancient city had an extended and well-constructed sewage systems as well as a water supply network since the Hellenistic period. The extended water supply networks developed and manufactured, since the ancient times (BC) due to the 
to uneven terrain and alternating layers of clay and limestone. Collected water was stored in water cisterns, which were connected to fountains with clay pipes.

In the Hellenistic and Roman periods the aqueduct of the island of Rhodes was an underground network of tunnels (called galleries), which were constructed within limestone (argolithia without binder), in various depths reached up to $70 \mathrm{~m}$. These tunnels are of varying lengths with wells (shafts or foggara) and stairs at intermediate distances ranged from $50 \mathrm{~m}$ to $60 \mathrm{~m}$. The wells were necessary for construction, operation, and maintenance purposes (Figure 12). A general view of the entrance in a well is shown in Figure 13. They have a sloping (inclined) section instead of a vertical one, which is the common case in the aqueducts-like qanats in the rest of the world. It is probably due to the differences in the geomorphology, the topography, and the local climatic and hydrological conditions.

Figure 12. Wells at the soil surface as appear today.

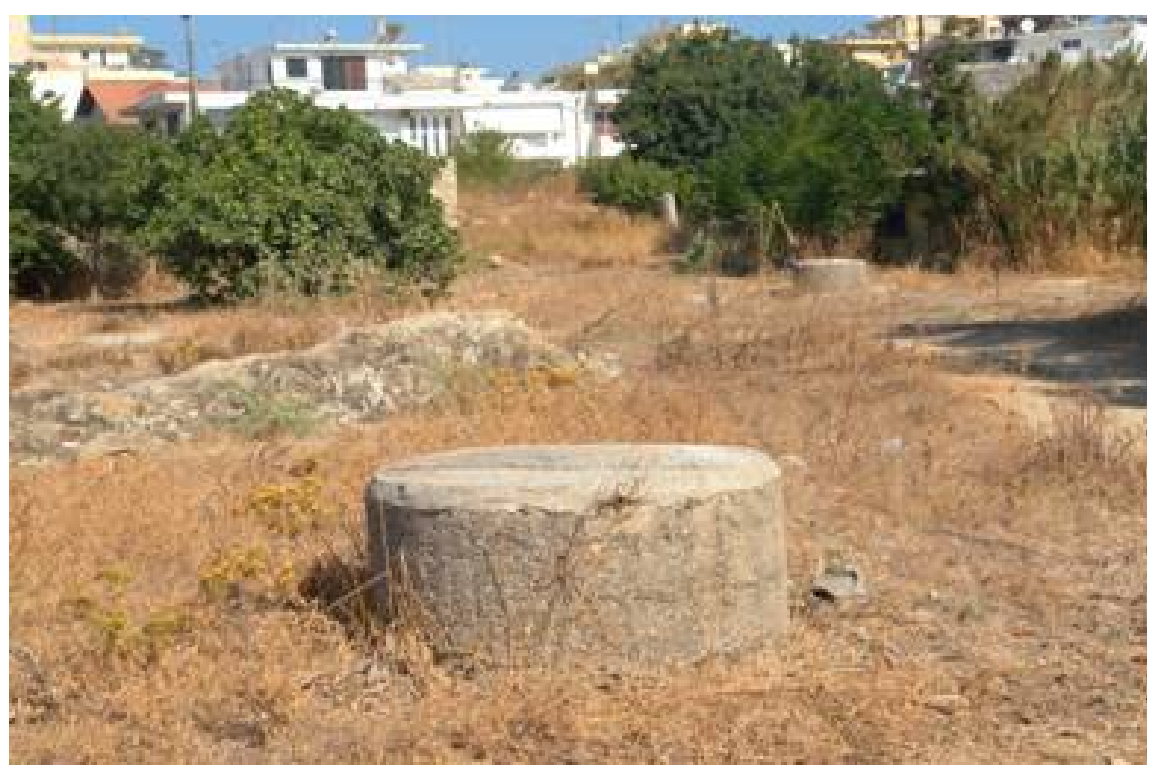

Figure 13. A general view of the entrance in a well (shaft).

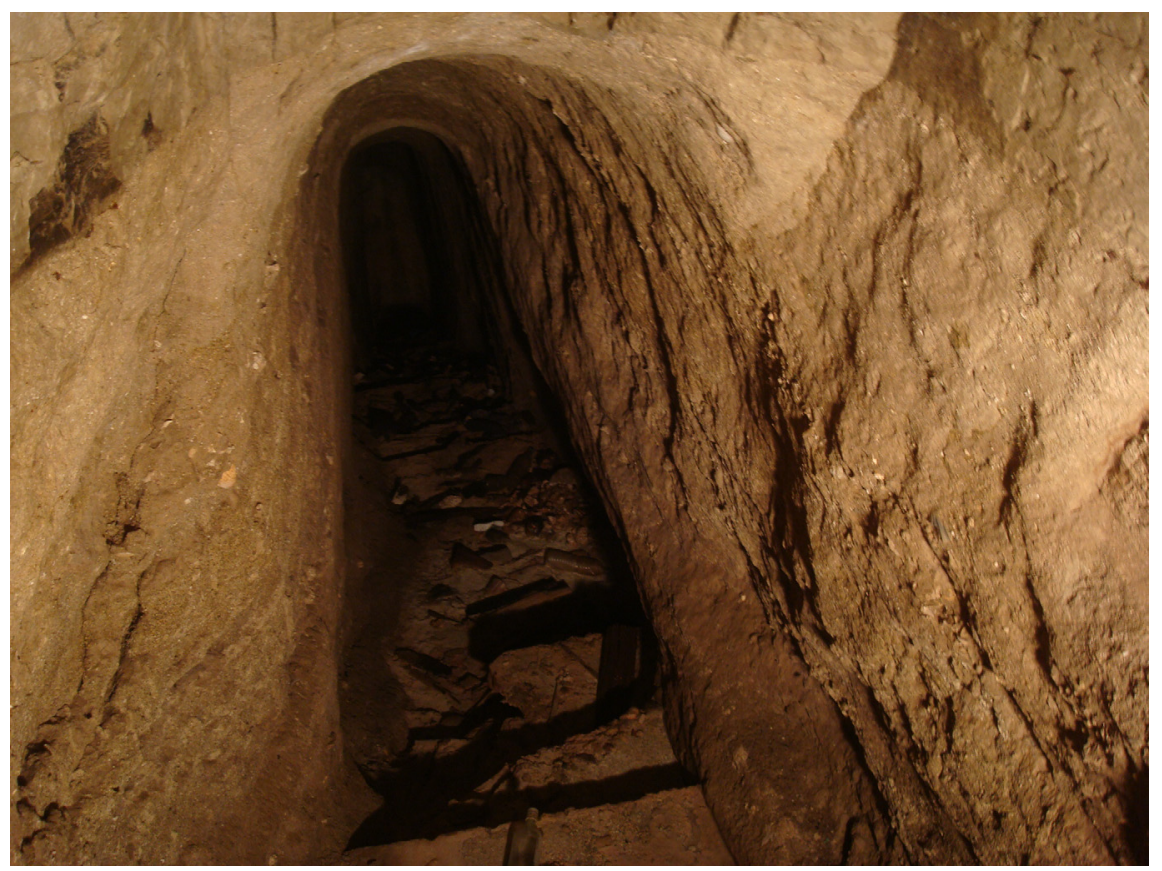


During the Ottoman period, maintenance and cleaning of tunnels were torn down (atonise), so many of these have been destroyed through the time. However, at the time of the Italian occupation, a restoration program of these tunnels started, which lasted more than a decade. A part of the restored tunnels and purification of water was launched in 1927 and its performance and operation covered the water needs of the town, until the early 1960s, despite its touristic development. It is estimated that a minimum length of $40 \mathrm{~km}$ tunnels were reconstructed and operated at that time. Along with the restoration of the tunnels in that decade, water cisterns were built in their ending sections for the storage purposes of the water. The four major tunnels according to their length which were restored at that time were: (a) Jeni-su; (b) Sandurli-su; (c) Inger-su; and (d) Tabahana-su. These tunnels end at the respective water cisterns bearing the same name. A schematic cross section (no scale) of the Jeni-su tunnel with a series of vertical wells (up to 24) is shown in Figure 14.

Figure 14. Schematic cross section of the tunnel Jeni-su in Rhodes with a series of vertical wells [23].

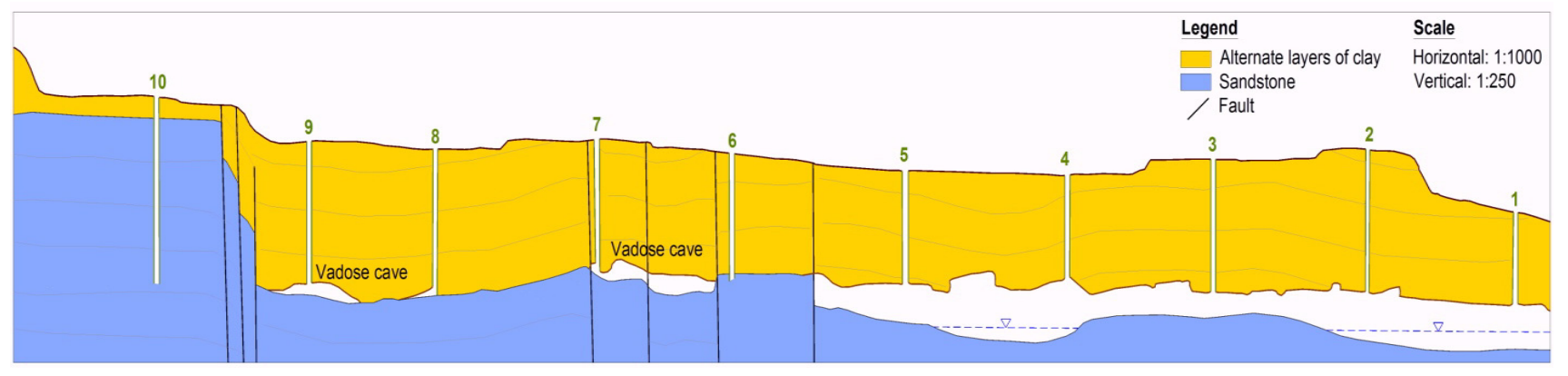

There is another smaller tunnel named Rodino-su, which ends in the unique creek, currently called Rodini, which exists and operates for recreational purposes. In addition, there is another tunnel, which was restored by the time of the Knights, which ends within the walls for obvious reasons at the time.

In 1963, the original water supply plan of the town was adopted, which did not affect the tunnels, since they were left off the plan. The tunnel of the area Tabahana Monte Smith and the tunnel, which fed the walled town, were not affected, as the development and the street plan was under protected archaeological sites. Thus, a large part of the water supply of the town continued, until recently, to come from the tunnels. After 1974, when the town expanded and the second phase of the water supply plan began to be implemented, the water of the tunnels was polluted by wastewater leachate from cesspools. Today the water of the tunnels is contaminated directly through their wells and indirectly from cesspools.

\section{Aqueducts like Qanats in the Area of Phyllida (Eastern Macedonia)}

The Phyllida area is part of the Aggitis river basin in Eastern Macedonia (Prefecture of Serres, North Hellas). The wider area has a continental climate, with wet winters and hot summers. The mean annual rainfall varies from $465 \mathrm{~mm}$ to $1100 \mathrm{~mm}$ in mountainous areas. A percentage of $65 \%$ of the total precipitation generally occurs in the wet period, which normally extends from late October through to April, with sparse storm events during the summer months [24].

In Phyllida more than 18 aqueducts-like qanats (Figure 15) of a length ranging from $35 \mathrm{~m}$ to $4000 \mathrm{~m}$ each are described by Vavliakis [25]. These hydraulic works are used for water supply of villages and 
monasteries since the Ottoman occupation (18th century), and most of them are still in operation today. Few of them are not in operation today due to destruction from floods and earthquakes, clogging of tunnel from branches of trees or shrubs roots, deposition of calcium salts, etc. [25-27].

Figure 15. Sites of aqueducts-like qanats evidence in Phyllida region, North Hellas (with permission of G. Andreou).
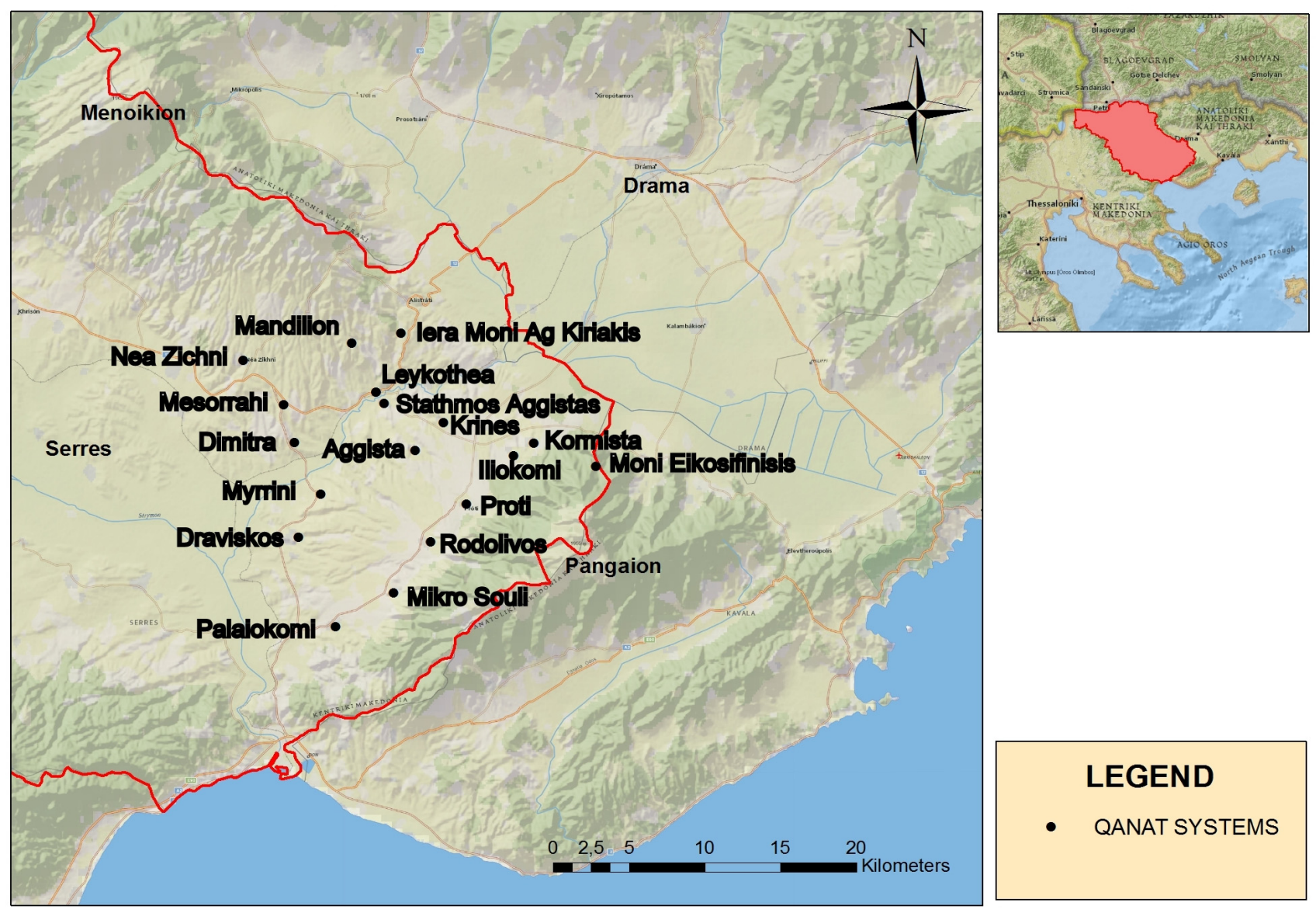

From a hydrogeological point of view, the Quaternary deposits of this area host an unconfined (phreatic) aquifer and the tunnels were used for the exploitation of this aquifer, except for some cases in which the tunnels were constructed in the contact of marbles and schists. The presence of the fault favors the groundwater outflow in the tunnel (Figure 16). The yield (discharge) of these tunnels ranges between $1 \mathrm{~m}^{3} / \mathrm{h}$ and $60 \mathrm{~m}^{3} / \mathrm{h}$, depending on the length of recharge zone, hydrological conditions, and season.

In a representative aqueduct-like qanat of Phyllida area (Figure 17), the initial well (mother well), and the sequence of wells (shafts), were dug in alluvial sediments and the bottom of the tunnel at the contact of permeable and impermeable deposits (metamorphic rocks, marls). Consequently, the phreatic aquifer of the area is exploited. The mother well is dug at the beginning of the aqueduct-like qanat where the groundwater table is close to the surface. The depth of the mother well is $12 \mathrm{~m}$. The depth of the shaft from ground level increases toward the mother well [26]. The tunnel of the aqueduct like qanat at Nea Zichni (Figure 16) had a length of one $\mathrm{km}$ and is used today to cover the water demands of the village [28]. The $\mathrm{Ca}-\mathrm{Mg}-\mathrm{HCO}_{3}$ water-type is the dominant water quality type in the Phyllida area, representing freshwater of recent infiltration. 
Figure 16. Plan (no scale) of an aqueduct-like qanat in the Phyllida area, Serres, Hellas [25].

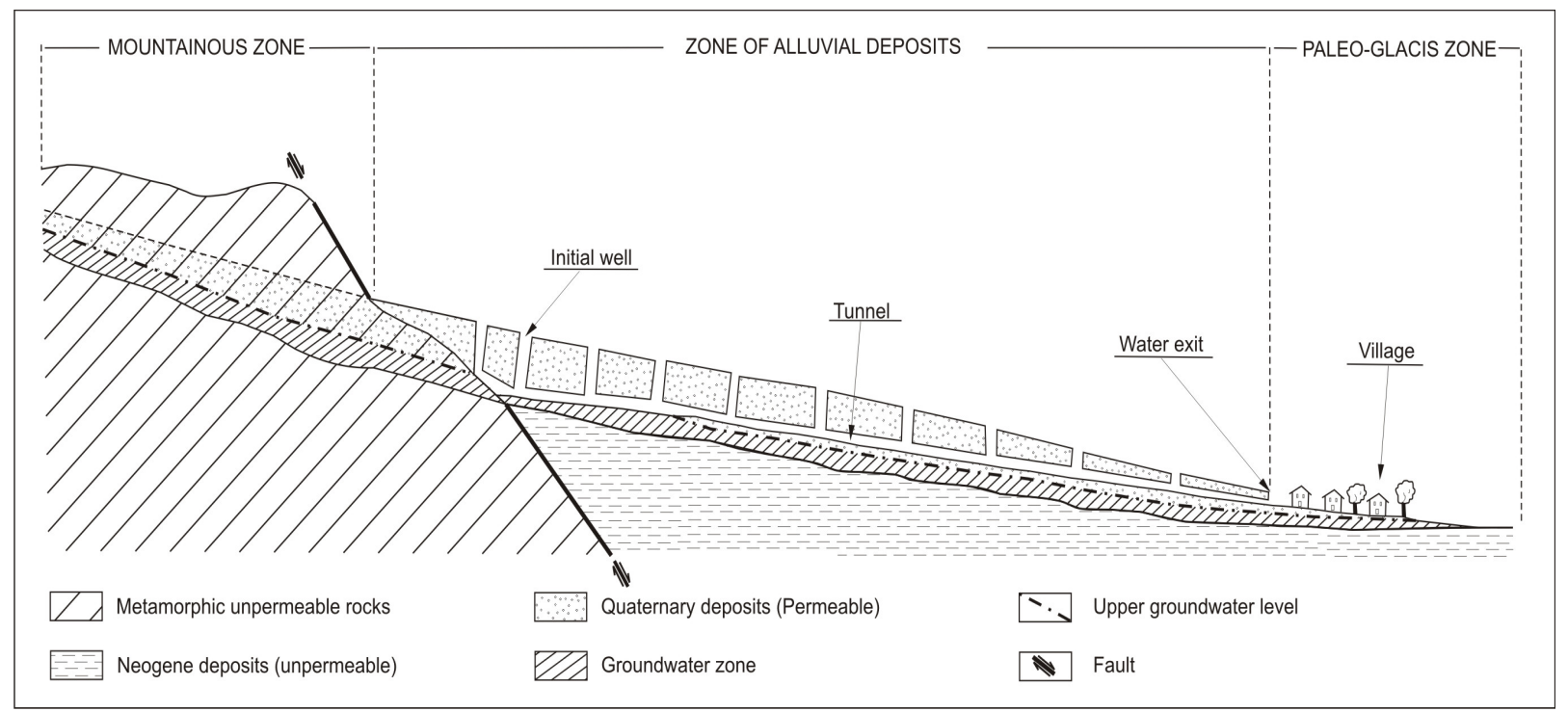

Figure 17. The tunnel of the aqueduct-like qanat in Nea Zichni constructed in the 18th century.

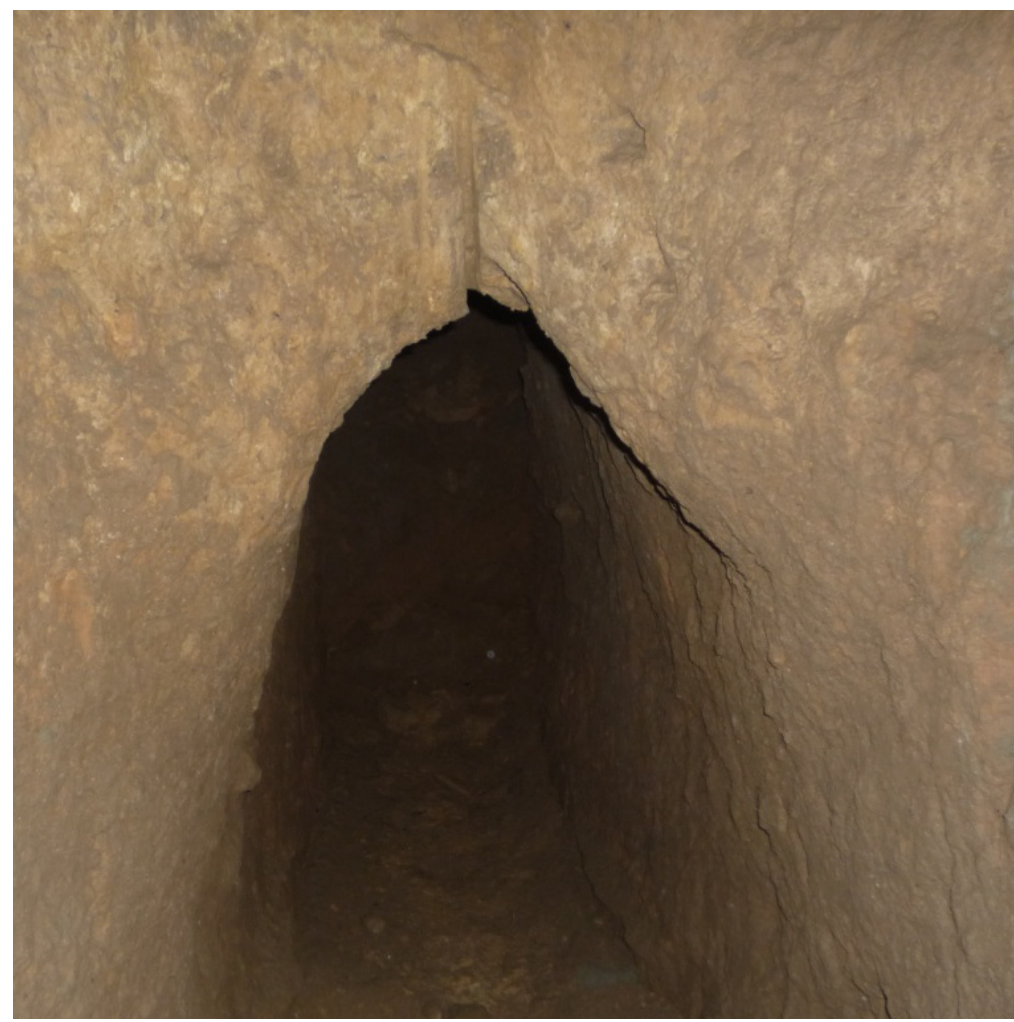

\section{Discussion and Conclusions}

In Hellas, a technique of tunneling was developed and used since, at least, archaic times. In Kopais basin (in Viotia, Central Greece), a tunnel with vertical wells was discovered. The impressive remnants of this hydraulic work represent the most important land reclamation effort, including tunneling drains of Mycenaean Hellas [29]. This work is dated within the Bronze Age, according to the indications from surface survey [30,31]. 
Another example is the well-known "tunnel of Eupalinos", which was constructed in the island Samos, Hellas (ca. 530 BC). Furthermore, several underground tunnels (with and without well-like vertical shafts) were constructed to convey water from one location to another located at a lower level. These types of hydraulic constructions have been reported as aqueducts [16-18] or as qanats $[13,24-26,32,33]$. Both terms have been used in several parts of the world for many centuries. However, when comparing their etymology/definition (Table 1), it should be effortlessly concluded that Qanat is identical to Aqueduct, or at least it is included therein. This should be clarified by establishment various categories of aqueducts.

Table 1. Etymology and/or definition of the terms "aqueduct" and "qanat".

\begin{tabular}{|c|c|c|}
\hline Aqueduct & Qanat or karez & Source \\
\hline $\begin{array}{l}\text { Aqueduct comes from the Latin word } \\
\text { aquceductus, which itself is from the roots } \\
\text { aqua, meaning "water", and ductus } \\
\text { (ducere), meaning "to lead". }\end{array}$ & & $\begin{array}{c}\text { Etymology } \\
\text { dictionary [34] }\end{array}$ \\
\hline An artificial channel for conveying water. & $\begin{array}{l}\text { A gently sloping underground channel } \\
\text { or tunnel constructed to lead water from } \\
\text { the interior of a hill to a village below. }\end{array}$ & $\begin{array}{l}\text { Oxford dictionary } \\
\qquad[35]\end{array}$ \\
\hline $\begin{array}{l}\text { An artificial channel that is constructed to } \\
\text { convey water from one location to another. }\end{array}$ & $\begin{array}{l}\text { It is a water management system used to } \\
\text { provide a reliable supply of water for } \\
\text { human settlements and irrigation in hot, } \\
\text { arid and semi-arid climates. }\end{array}$ & Wikipedia [36] \\
\hline $\begin{array}{l}\text { A conduit used to convey water over a long } \\
\text { distance, either by a tunnel or by a bridge. }\end{array}$ & It is an underground irrigation channel. & $\begin{array}{c}\text { Collins dictionary } \\
{[37]} \\
\end{array}$ \\
\hline \multirow[t]{2}{*}{$\begin{array}{c}\text { Conduit built to carry water from its source } \\
\text { to a main distribution point }\end{array}$} & $\begin{array}{c}\text { A qanat or karez is a water management } \\
\text { system used to provide a reliable supply } \\
\text { of water to human settlements or for } \\
\text { irrigation in hot, arid and semi-arid } \\
\text { climates. }\end{array}$ & $\begin{array}{l}\text { Webster's dictionary } \\
{[38]}\end{array}$ \\
\hline & $\begin{array}{l}\text { The conducts water from the level of an } \\
\text { aquifer to the open air by means of } \\
\text { simple gravity in order to distribute it to } \\
\text { lower areas. }\end{array}$ & $\begin{array}{c}\text { Encyclopedia Iranica } \\
{[39]}\end{array}$ \\
\hline
\end{tabular}

Today concerns over water shortages increase in several areas of the world and the benefits of water conservation are extolled, it is likely that the emerging market for looking of other technologies will grow. In our country ancient wisdom must put into practice by creating awareness, undertaking policy research, and lobbying to bring about change in policy, as required, so that water management is decentralized and water availability and sustainability increased. That was the case in ancient Hellas and, particularly, in the dry islands in the southeastern areas of the country. One very common technology was various types of aqueducts.

The first evidence of the use of aqueducts for water supply in Hellenic settlements lies in the Minoan era. However, that technology was tremendously further developed through history, mainly by enlargement the scale of the projects, with a peak in the Classical and Hellenistic periods. The 
technology of aqueducts matured and evolved during latter stages of the Classical period with a peak in the Hellenistic period, supported by the understanding of natural processes and the development of scientific concepts. At that period, even aqueducts-like qanats were developed (Table 2).

In conclusion it is believed that the aqueducts in Athens and Polyrrhenia were constructed in the Classical and Hellenistic periods and operated mainly during the Roman period and possibly over Hadrian, according to the fragments of a Latin inscription. The aqueducts were a public work and their external configuration and operation were subjected profound changes throughout the centuries. Probably, the entrance in the second aqueducts in Polyrrhenia has shifted in its today that is occupied by houses. Its tower was built on the rock-cut cave channel and opens up the external water cistern. It is a fact that the tower is in the line of Hellenistic fortification; but the building is not distinguished in earlier construction phases. Thus, what was the purpose to build it? The position of the building control passes to the south. The quality of the water is excellent, even today. Perhaps the caretakers of the aqueducts and fountains have their place there?

Table 2. Characteristics of major aqueducts-like qanats in Hellas $[16,40]$.

\begin{tabular}{|c|c|c|c|c|c|}
\hline Name & Location & Period & Construction & $\begin{array}{c}\text { Length } \\
(\mathbf{k m})\end{array}$ & $\begin{array}{c}\text { Flow rate } \\
\left(\mathrm{m}^{3} / \text { day }\right)\end{array}$ \\
\hline $\begin{array}{l}\text { Peisistratean, Athens } \\
\text { (terracotta pipes in shallow) }\end{array}$ & Athens & Classical & Late 6th century BC & & \\
\hline $\begin{array}{l}\text { Hymettos (tunnel and } \\
\text { wells up to } 14 \text { m deep) }\end{array}$ & Athens & Classical & $\begin{array}{c}\text { Late } 5 \text { th or early } 4 \text { th } \\
\text { century BC }\end{array}$ & 6.5 & \\
\hline $\begin{array}{l}\text { Acharnian (elliptical terracotta } \\
\text { tubes in shallow trench) }\end{array}$ & Athens & Classical & Early 4th century BC & 19.5 & \\
\hline $\begin{array}{l}\text { Long Walls aq. (shallow } \\
\text { tunnel and wells) }\end{array}$ & Athens & Unknown & Unknown & $\sim 9$ & \\
\hline Pangaio Mountain & Serres-Kavala & Classical & 4th century BC & 20 & \\
\hline Polyrrhenia, aqueduct 1 & Polyrrhenia & Classical & 4th century BC & & \\
\hline Polyrrhenia, aqueduct 2 & Polyrrhenia & Classical & 4th century BC & & \\
\hline Rhodes & Rhodes & $\begin{array}{l}\text { Hellenistic- } \\
\text { Roman }\end{array}$ & & 40 & \\
\hline Phyllida, Serres (18) & Macedonia & Ottoman & & $0.1-4.0$ & $24-1440$ \\
\hline
\end{tabular}

This technology was extended to the Roman period in Rhodes, which was in operation during the Venetian and Ottoman periods. In addition, the aqueducts (qanats) constructed in the Phyllida area (Eastern Macedonia, Hellas) are of Ottoman period. In general, the shallow alluvial aquifer is exploited via numerous (18) aqueducts-like qanats covering the water demands until now. The length of these hydraulic works is ranged from $100 \mathrm{~m}$ to $4000 \mathrm{~m}$ and their capacity from $1 \mathrm{~m}^{3} / \mathrm{h}$ to $60 \mathrm{~m}^{3} / \mathrm{h}$. The water quality is characterized by the dominant $\mathrm{Ca}-\mathrm{HCO}_{3}$ type, representing fresh water in recharge areas.

The restoration and preservation of the aforementioned aqueducts-like qanats, as elements of our cultural heritage is necessary. Furthermore, the study of ancient hydraulic works including aqueducts-like qanats, will help to face present water problem in areas, which are facing similar problems of water shortage as they did in the past. 


\section{Acknowledgments}

The critical comments of Stathis Chiotis and the valuable information of Panayiotis Kanakis, Water Supply and Sewerage Systems Municipal Enterprise of Rhodes, are highly appreciated. The authors greatly appreciate the valuable comments of the reviewers. Also, part of this paper will be presented in the IWA Workshop on Traditional Qanats Tecnologies, in Marrakesh, Morocco, 24-26 October 2013.

\section{Conflicts of Interest}

The authors declare no conflict of interest.

\section{References}

1. Angelakis, A.N.; Savvakis, Y.M.; Charalampakis, G. Aqueducts during the minoan era. Water Sci. Technol. 2007, 7, 95-102.

2. Mays, L.W.; Koutsoyiannis, D.; Angelakis, A.N. A brief history of water in antiquity. Water Sci. Technol. 2007, 7, 1-12.

3. Jansen, M. Water supply and sewage disposal at mohenjo-daro. World Archaeol. 1989, 21, 177-192.

4. Adams, R. Heartland of Cities: Surveys of Ancient Settlements and Land Use on the Central Floodplain of the Euphrates; University of Chicago Press: Chicago, IL, USA, 1981.

5. AbdelKhaleq, R.A.; Alhaj-Ahmed, I. Rainwater harvesting in ancient civilizations in Jordan. Water Sci. Technol. 2007, 7, 85-94.

6. Hassan, F.A. Water management and early civilizations: From cooperation to conflict. In History and Future of Shared Water Resources, PCCP Series No 6; Hassan, F.A., Reuss, M., Trottier, J., Bernhardt, C., Wolf, A.T., Mohamed-Katerere, J., van der Zaag, P., Eds.; UNESCO: Paris, France, 2003.

7. Schacht, I. A preliminary survey of the ancient qanat systems of the northern kharga oasis. Mitt. Dtsch. Archaol. Inst. 2003, 59, 411-423.

8. Lightfoot, D.R. The origin and diffusion of qanats in arabia: new evidence from the northern and southern peninsula. Geogr. J. 2000, 166, 215-226.

9. Wulff, H.E. The Qanats of Iran. Scientific American, April 1968; pp.94-105. Available online: http://users.bart.nl/ leenders/txt/qanats.html (accessed on 10 October 2011).

10. Garbrecht, G. Meisterwerke Antiker Hydrotechnik (Masterpieces of Antique Hydrotechnology); Springer: Teubner, Germany, 1995.

11. Margat, J.; van der Gun, J. Groundwater around the World: A Geographic Synopsis; CRC Press/Balkema: Leiden, The Netherlands, 2013; p. 343.

12. Martínez-Santos, P.; Martínez-Alfaro, P.E. A brief historical account of Madrid's qanats. Ground Water 2012, 50, 645-653.

13. Weingartner, H. Water Supply by Qanats: A Contribution to Water Shortage in Mediterranean Areas. In Proceedings of the 10th International Conference on Environmental Science and Technology, Kos island, Greece, 5-7 September 2007; pp. 1555-1561.

14. Crouch, D.A. Water Management in Ancient Greek Cities; Oxford University Press: New York, NY, USA, 1993. 
15. Zarkadoulas, N.; Koutsoyiannis, D.; Manassis, N.; Angelakis, A.N. A brief history of urban water management in Ancient Greece. In Evolution of Water Supply through the Millennia; Angelakis, A.N., Mays, L.W., Koutsoyiannis, D., Mamassis, N., Eds.; IWA Publishing: London, UK, 2012; pp. 259-270.

16. Chiotis, E.; Marinos, P. Geological aspects on the sustainability of ancient aqueducts of Athens. Bull. Geol. Soc. Greece 2012, XLVI, 16-38.

17. Chiotis, E. Aqueducts and drainage works in the ancient Agora of Athens. In The Agora in the Mediterranean from Homeric to Roman Times; Giannikouri, A., Ed.; Ministry of Culture: Athens, Greece, 2011; pp.165-180.

18. Chiotis, E.; Chioti, L. Industrial activities in the ancient Agora of Athens in the Late Roman times. In The Agora in the Mediterranean from Homeric to Roman Time; Giannikouri, A., Ed.; Ministry of Culture: Athens, Greece, 2011; pp.181-196.

19. Chiotis, E.D.; Chioti, L.E. Water supply of Athens in the antiquity. In Evolution of Water Supply through the Millennia; Angelakis, A.N., Mays, L.W., Koutsoyiannis, D., Mamassis, N., Eds.; IWA Publishing: London, UK, 2012; pp. 407-442.

20. Christodoulakos, Y.; Markoulaki, S. Water Supply of Polyrrhenia. In Proceedings of the 11th International Cretological Congress, Rethymnon, Greece, 21-27 October 2011.

21. Saragosa, C. L' insediamento Umano, Ecologia e Sostenibilità (in Italics); Donzelli Editore: Roma, Italy, 2005; pp. 243-245.

22. Chaudhur, K.N.L. Asia prima dell' Europa, Economie e civiltà dell' Oceano Indiano, Donzelli editore (in Italics); Cambridge University Press: Cambridge, UK, 1990, pp. 86-89.

23. DEYAR. Municipal Enterprise of Water Supply and Sewerage of Rhodes Town; Unpublished Technical Report, DEYAR: Rhodes, Greece, 2011.

24. Vavelidis, M.; Giouri, A.; Voudouris, K.; Vaxevanopoulos, M. Regional geology and its impact on water supply in the Pangeon and Menikion mountains (N. Greece). In Landscape and Sustainable Development: Water-Contributions to Sustainable Supply and Use; Weingartner, H., Blumenstein, O., Vavelidis, M., Eds.; University of Salzburg: Salzburg, Austria, 2012; pp.15-29.

25. Vavliakis, E. The Qanat Systems in Greece: A study of Qanat systems in Phyllida of Serres from Morphological, Hydrographic and Socio-Economical View (in Greek). Habilitation Thesis, Department of Geology, Aristotle University, Thessaloniki, Greece, 1989; p. 93.

26. Blumenstein, O.; Weingartner, H.; Vavelidis, M. Qanats between Menikion and Pangeon Mountains: A Forgotten and Endangered Resource for Local Water Supply. In Proceedings of 19th Congress of the Carpathian Balkan Geological Association, Thessaloniki, Greece, 23-26 September 2010; pp. 23-29.

27. Yazdandoost, F. Qanat, a Source of Sustainability in Arid and Semiarid Regions through History. In Proceedings of 3rd Specialized Conference on Water and Wastewater Technologies in Ancient Civilizations, Istanbul, Turkey, 22-24 March 2012; pp. 59-64.

28. Voudouris, K. Diachronic evolution of water supply in eastern Mediterranean. In Evolution of Water Supply through the Millennia; Angelakis, A.N., Mays, L.W., Koutsoyiannis, D., Mamassis, N., Eds.; IWA Publishing: London, UK, 2012; pp. 77-89. 
29. Kountouri, E.; Petrochilos, N.; Oikonomou, V.; Koutsoyannis, D.; Mamasis, N.; Zarkadoulas, N.; Vött, A.; Hadler, H.; Henning, P.; Willershäuser, T. The Mycenaean drainage works of north Kopais, Greece: A new project incorporating surface surveys, geophysical research and excavation. Water Sci. Technol. 2013, 13, 710-718.

30. Knauss, J. Arcadian and boiotian Orchomenos, centres of mycenaean hydraulic engineering. Irrig. Drain. Syst. 1991, 5, 363-381.

31. Koutsoyiannis, D.; Angelakis, A.N. Agricultural hydraulic works in ancient Greece. In The Encyclopedia of Water Science; Stewart, B.A., Howell, T., Eds.; Dekker: New York, NY, USA, 2004; pp. 415-417.

32. Kleidopoulou, M. Groundwater Flow to Hydraulic Works. An Example from the Almyros Area (Heraklion, Crete). Ph.D. Thesis, Technical University of Crete, Department of Mineral Resources Engineering, Chania, Greece, 2003; p. 406.

33. Vavliakis, E.; Sotiriadis, L. Die aktiven Qanat systeme in Griechenland. Untersuchung der aktiven Qanatsysteme in der Provinz Phyllis (Serres) aus morphologischer und hydrographischer Sicht. In Festschrift Helmut Riedl, Salzburger Geographische Arbeiten 25; Kern, W., Stocker, E., Weingartner (Hrsg); Selbstverl. des Inst. für Geographie der University, Salzburg, Austria, 1993; pp. 193-205.

34. Etymology Dictionary. Available online: http://en.wikipedia.org/wiki/Etymological_dictionary (accessed on 1 July 2013).

35. Oxford Dictionary. Available online: http://en.wikipedia.org/wiki/Oxford_English_Dictionary (accessed 3 July 2013).

36. Wikipedia. Available online: http://www.wikipedia.org/ (accessed on 1 July 2013).

37. Collins Dictionary. Available online: http://www.collinsdictionary.com/dictionary/english/facinorous (accessed on 3 July 2013).

38. Webster's Dictionary. Available online: http://www.merriam-webster.com/ (accessed on 3 July 2013).

39. Encyclopedia Iranica. Available online: http://www.iranicaonline.org/. (accessed on 1 July 2013).

40. De Feo, G.; Mays, L.W.; Angelakis, A.N. Water and wastewater management technologies in ancient greek and roman civilizations. In Treatise on Water Science; Wilderer, P., Ed.; Academic Press: Oxford, UK, 2011; pp. 3-22.

(C) 2013 by the authors; licensee MDPI, Basel, Switzerland. This article is an open access article distributed under the terms and conditions of the Creative Commons Attribution license (http://creativecommons.org/licenses/by/3.0/). 